\title{
British biotechnology boat comes home
}

The plan to set up a British biotechnology company, much talked of recently (Nature, 5 June) came into the open this week. A company has been set up with an initial capital of $£ 12$ million, between 40 and 50 per cent of which will be provided by the National Enterprise Board. It is hoped that it can be registered as Celltech, but the formalities had not been completed on Monday.

The managing director will be Mr Gerard Fairtlough, until two years ago joint managing director of Shell UK Limited with responsibility for the $£ 300$ million turnover of the petrochemical part of the enterprise, and who has since then been a division head at the NEB.

Mr Fairtlough said this week that the NEB had been looking at the opportunities in biotechnology since the early autumn of last year, when it commissioned a study of the opportunities, apparently from Professor J D Watson, director of the Cold Spring Harbor Laboratory in the United States. At that stage the NEB had not known that Sir Alf Spinks was working on a report on biotechnology for the Advisory Council on Applied Research and Development (ACARD).

The new company will be jointly owned by the NEB (the largest shareholder) and four commercial partners - the Prudential Assurance Company Limited, the Midland Bank Limited, Finance for Industry and British and Commonwealth Shipping Limited. It is intended that roughly a third of the board of the company should be molecular biologists.

The new company plans to recruit between 50 and 75 people over the next two years. It will not build a laboratory of its own but will use existing premises. The location has not been finally decided, but may well be in Cambridge.

The company has taken trouble to come to good terms with the Medical Research Council, and claims that it has a "framework for collaboration" that will allow it to place contracts with MRC laboratories and to have access to MRC "ideas". The embryo company has also been talking to two other institutions, not openly identified but probably including the Imperial Cancer Research Fund.

$\mathrm{Mr}$ Fairtlough says that particular trouble has been taken to study the ways in which molecular biologists might be involved with the new company. Appreciating that some may wish to make money out of their skill, and that others are offended by the notion, it is planned that the company will make commercial arrangements only with the institutions to which people belong, leaving them to decide how individuals should be paid.

At the outset, the new company will make and sell monoclonal antibodies, but will also explore longer-term projects. It is laid down that the company should make

money out of something within two or three years. The phrase "lean and hungry" is much used. The first opportunities will, it is said, be in the field of diagnostic tests.

At the same time, the NEB is anxious that the company should be financially strong enough to tackle "big things". The company will not always seek to market its own products to their ultimate users, but will be content with selling licences for manufacture by others where that seems the best course to follow.

The board of the NEB itself is said to be pleased at having launched its first "constructive project" - since the previous board resigned en bloc last November, the board has been primarily concerned with housekeeping. The fact that the NEB rather than the National Research Development Corporation has become the chief public sponsor of the new

\section{Supreme Court stirs up more fear}

\section{Washington}

Recombinant DNA research is moving from the frying pan to the fire. Last month's decision by the US Supreme Court to permit the patenting of live microorganisms has started a new round of public debate about the conditions under which recombinant DNA research should be carried out.

When the National Institutes of Health formulated safety guidelines in 1976, the main concern was the potential health hazard. Attention is now concentrated on the rights of ownership and control over natural processes.

The Supreme Court ruling has crystallized various areas of concern. Several scientists, for example, have expressed their fears that the decision to allow a patent on a strain of Pseudomonas bacterium, developed by research workers with the General Electric Company by inserting foreign plasmids, could create barriers to the free flow of research ideas. Others disagree, claiming that the requirement to publish details of a patent ensures that the information will be publicly available. And the American Society for Microbiology is sponsoring a meeting in Washington this week to explore such areas of disagreement.

The ASM meeting will debate "the proper role of the patent laws in genetic research and development". Questions to be discussed include that of whether the law should be modified to preclude exclusivity or monopoly over a microorganism; and, more generally, whether the decision is consistent with the objectives of the microbiological and biomedical scientific communities.

Professor Emilio Schaechter, chairman of the committee organizing the ASM meeting, highlights one particular area needing attention, that of how research biotechnology company is not only a sign of its skill but a mark of the disfavour in which the NRDC finds itself with academic scientists in general and those working for the Medical Research Council in particular.

On the question why the present British government may have sanctioned this modest investment, $\mathrm{Mr}$ Fairtlough said that the involvement of private capital had been a necessary condition, given "the way our guidelines have been evolving". He said that the new company would succeed if it could show that it had a "distinctive competence" and if it combined a hardheaded appraisal of the market with a capacity to make better use of people's talents. He considers that Celltech will be able to establish better relations with academic scientists than companies such as Gènetech and Biogen.

using recombinant DNA techniques should be regulated in the private sector. Although NIH operate a system of voluntary compliance with their safety guidelines, they have no desire to act as a full-blown regulatory agency. NIH are considering delegating most safety decisions to local biohazard committees, and there is concern that the regulatory apparatus may be inadequate.

The Department of Labor's Occupational Safety and Health Administration is already taking steps to define its own role, including setting up a committee to outline voluntary control of the exposure of workers to processes involving recombinant DNA techniques.

Both the closeness of the Supreme Court decision - a five to four majority - and the justices' opinions on both sides provide an open invitation to Congress to look more closely at the patenting question. The four minority justices wrote "it is the role of Congress, not of the court, to broaden or narrow the reach of the patent laws". For the majority, Chief Justice Warren Burger admitted that the court's decision had been reached on a narrow interpretation of present patent law and added that Congress was free to amend the law to exclude from patent protection organisms produced by genetic engineering, or to "craft a statute specifically designed for such living things"'

Pope John Paul II warned in an address to Unesco that genetic manipulation might be applied to "ends contradictory to those of humanity". Four days after the Supreme Court's decision was announced, religious groups representing Protestant, Catholic and Jewish viewpoints issued a statement which said that the questions raised by genetic engineering - who should control it, who would benefit and 
who might bear adverse consequences dealt with "the fundamental nature of human life".

Finally, the whole issue may come under review by the newly established President's Commission for the Study of Ethical Problems in Medicine and Biomedical and Behavioural Research. Following an approach from the National Council of Churches, the commission is exploring whether any major reviews of the ethical implications of genetic manipulation are already in progress. If not, the subject might be selected for study by the commission when it meets in September.

David Dickson

Biotechnology

\section{European setback}

Brussels

THE European Commission's programme of research in biotechnology was seriously set back last week, when a meeting of CREST failed to endorse the programme or even to agree on a compromise. Over the past four years, the commission has developed a plan for spending $£ 28$ million over the next five years (half of it to be supplied by national governments) on a number of projects.

France was the chief stumbling block at last week's meeting of CREST, the committee which advises the European Community on research and development policy. French representatives argued for an alternative programme of fellowships to help train potential genetic engineers. The meeting of CREST was the last at which the biotechnology programme will be considered - a decision on what to do now rests with the Council of Ministers of the European Community, on which France will be able to exercise its veto.

According to reliable national sources, the council will have to choose between the commission's original plan, the French proposal and a compromise between the two supported by the United Kingdom. That would entail spending a total of $£ 18$ million over only four years and the elimination of some of the research projects proposed by the commission.

The CREST decision has caused much ill-feeling among European states. West German delegates at the meeting last week supported the French position, but more flexibly. One angry Dutch observer said last week that the smaller European states would feel misled by the larger states. An Italian offical said that France had opposed the commission's plan because it wished to keep all projects with "pace" to itself.

The difficulty now is that the Council of Ministers, when considering the biotechnology programme, will be advised by an ad hoc scientific subcommittee of COREPER - the committee of community ambassadors in Brussels, which is well used to taking political considerations into account. It could, for example, think of trading an agreement on the biotechnology programme for an agreement on sheepmeat.

There is nevertheless a chance that a compromise proposal may be adopted, if Germany can be persuaded to agree. The compromise would involve restricting the research projects to:

- the development of new reactors involving immobilized multi-enzyme systems;

- the transfer of genes to Escherichia coli, Saccharomyces cerevisiae, and other organisms;

- gene transfer in microorganisms and plants important important to agriculture; - safety studies.

The compromise also emphasizes mobility of manpower, in line with the French proposals, by devoting 30 per cent of the budget to training of foreign nationals in national laboratories, training of industrial scientists in university laboratories, and short courses in biohazards and safety measures. However, the French proposal does not mention safety questions, which must be satisfactorily answered if public confidence in the emerging technology is to be maintained.

In Britain, the possible demise of the European initiative is seen more as a danger signal than as an unmitigated disaster. Dr Duncan Davies, Chief Scientist at the Department of Industry, and chairman of the Cabinet Official Committee on Biotechnology which has just produced a draft White Paper on biotechnology in Britain, told the House of Lords recently that the commission programme - as it would affect the UK - would amount to only 10 per cent of the probable British effort over the next five years.

At Imperial Chemical Industries Limited, which probably has the most advanced industrial biotechnical team in Britain, the loss of the European programme is seen as less sad for ICI than for "UK Limited". Things could be done on the European scale, said Dr Bernard Langley of ICI's Policy Group last week, "which would help everyone". Coordinating safety standards and experimentation and developing new host-vector systems were examples.

In academic circles, where the UK Spinks report on biotechnology recommended an immediate injection of 20 new posts, and cash, the loss of commission money is taken more seriously. "Unless we have more posts soon, we are in deep trouble"' said one leading biotechnologist last week. "And I see no sign at all of the Department of Education and Science taking an intelligent interest in the issue." The loss of the European programme could be the end.

The draft version of the White Paper currently in circulation also may be little consolation to Britain's biotechnologists. According to one comment, "it offers everything short of real help"'.

Robert Walgate
Yugoslav academics

\section{No liberalization}

At least for academics and scientists in Yugoslavia, there seems to be little sign of the liberalization expected to follow Tito's death.

Ivan Supek, a leading Yugoslav nuclear physicist and an active participant in the Pugwash movement, has just published in Britain a defence of his view that scientific research must be based on ethical principals, and of his resolute opposition to nuclear weapons. His views, he claims, have been consistently misrepresented by the official Communist press, which treats him, at best, as some kind of Don Quixote.

Supek, who is now head of the Institute of the History and Philosophy of Science in Zagreb, was formerly in charge of the Rudjer Boscovic Institute of Theoretical Physics in Zagreb. While working there, he watched with increasing alarm the development of a nuclear institute on the outskirts of Belgrade where, he suspected, preparations were being made for the development of nuclear weapons.

His own anti-nuclear campaign of the 1960s was, he says, only one aspect of a growing discontent among intellectuals and scientists, who felt their status had been devalued by the Party in the name of the working class. The University of Zagreb's 300th anniversary in 1969 was seized on by the academics as a unique opportunity to redress the balance.

The appearance of Supek's apologia coincides with an appeal to the world academic community by seven professors from the University of Belgrade for support in their campaign against the latest revision of the Serbian law on universities.

These lecturers were closely associated with the philosophical journal Praxis, founded in the mid-1960s as the organ of the Croatian Society for Philosophy. Originally in the hands of Zagreb academics who took a generally social democratic line, it gradually became associated with the more liberal-marxist Belgrade philosophers. Finally, it was closed in 1975, and eight lecturers were suspended. They were not allowed to teach, lecture or publish; they did, however, draw a reduced salary and could benefit from the free health service.

Their status will however be radically changed by the revision of Serbian law on universities, passed on 5 June. Under the previous law, (introduced in 1974) lecturers could be suspended if they "damaged social interests". Under the new law, they can be sacked after two years' suspension. Persons already suspended for more than two years will be sacked in six months' time. The seven lecturers still under suspension (one has since found another post) maintain that this law has been brought in specifically to deal with their case. They further state that it is unconstitutional, being against the 